tudes have not only been spared but have avoided competitive extinction because of the 'intermediate disturbance' of falling trees, or the dispersal forced by predators. Both processes should prevent winner-take-all competition from driving the losers from existence.

Only one current hypothesis invokes the more fundamental idea of enhanced speciation in the tropics, the so-called refugial hypothesis of Jurgen Haffer. This hypothesis seeks to explain disjunct distributions of Amazon birds and butterflies by imagining a time of aridity in the last ice age that should have divided the Amazon forest, letting speciation proceed in forest fragments as it does on islands in the sea. On this thinking, a speciation episode should happen with every glacial cycle, as the forest was first broken, then remerged, with the changing of the rains.

Terborgh lists only two "faint" voices that doubt the reality of this model, John Endler's and mine. Endler points out the gross lack of parsimony, whereas I base my whimpering on testing the proposed history with palaeoecological data. Initial results from the ice-age Amazon suggest cooling, with concentration of the forest in the supposedly arid lowlands.

Terborgh develops a new insight from the discussion, at once novel and appealing. Vicariance events (that is separation into 'other' isolated populations before

\section{The flight of the speedy bee}

Thomas D. Seeley

Killer Bees: The Africanized Honey Bee in the Americas. By Mark L. Winston. Harvard University Press: 1992. Pp. 155. \$19.95, £15.50.

SOME 35 years ago, several dozen queen honey bees from Africa were imported into Brazil for cross-breeding with other honey bees already there, with the aim of producing a bee well suited to tropical conditions. Shortly after its introduction, some of the African stock escaped and became established as a feral population in central Brazil. From here, the population spread roughly 500 kilometres a year, colonizing most of tropical and subtropical America and displacing other subspecies of the honey bee, previously imported from Europe. At present, the colonizing front of the Africanized bee is within the state of Texas, and over the next several years it is expected to spread throughout the southern third of the United States, stopping only when it reaches regions with harsh winters.

Long before the Africanized bee remerging) need to be of the order of 100,000 years long for critical genetic changes to take place. Ice-age cycles are of this order. The pacemaker of ice ages is perturbation of the Earth's orbit and tilt, an effect known to palaeoclimatologists as Milankovitch climatic change. Terborgh suggests the tantalizing possibility that most speciation since the dawn of life has been driven by Milankovitchinduced vicariance cycles. Fine though the idea is, a sceptic would contend that Milankovitch climatic change, outside glacial cycles, is too subtle for the requirements of vicariance.

This book is the most accessible, and best, review of the properties and intrigue of rainforests. Tales are told about Terborgh and his prowess as an Amazonian biologist. He writes with the passion of unexcelled knowledge about the wonders and possibilities of rainforests. His prognosis for their future in a world beset by excess human reproduction is sober - essentially, he believes that the forests cannot survive without cultural changes in human societies, changes that will take too long. In the name of whatever gods may be, give us money and people to catalogue and question in the last decades before the forest is all gone.

Paul Colinvaux is at the Smithsonian Tropical Research Institute, PO Box 2072, Balboa, Panama.

reached North America, it had been nicknamed 'the killer bee', with journalistic reports, books and films produced in the United States all focusing on lurid tales of death by stinging, and causing considerable alarm. Now that the bee is in the United States and there to stay, it is time for more responsible journalism. In Killer Bees, Mark Winston encourages the spread of sound information about the Africanized bee by providing a concise, factual introduction to its biology. This book is not intended to serve as a detailed scholarly review for specialists (for this, one should consult two recent books: Africanized Honey Bees and Bee Mites, Ellis Horwood, 1988 and The "African" Honey Bee, Westview Press, 1991, the former by Glen Needham et al., the latter by Marla Spivak et al.); rather, it is aimed at general readers such as local government officials and the public, and the commercial beekeepers who will deal daily with the bee.

The book consists of two parts. In part one, "Biology and Habits", Winston draws on his years of first-hand experience with Africanized bees in French Guiana, Venezuela and Peru to describe these insects' traits and to explain their adaptiveness for tropical life. The reader learns, for example, that the feistiness of this bee has its roots in millions of years of intense predation in Africa by such adversaries as ants, honey badgers and especially humans. Hence, ultimately, the problem of the Africanized bee is one of our own making. More importantly, Winston explains that the principal problem that beekeepers will face is the bee's tendency to swarm (that is, to undergo colony fission for reproduction), to build small colonies and to store only a little honey. Beekeeping in North America currently relies on bees of European origin, which were shaped by natural selection to swarm infrequently and to form large colonies with large honey stores, thereby enabling them to survive cold winters. By contrast, the traits of Africanized bees are superior where there is no hurdle of winter survival, but where there is a premium on rapid reproduction to exploit new or under-used habitats.

In part two, "Impact and Control", Winston reviews the consequences of the Africanized bees' traits for the general public, but especially for beekeepers. Here he draws upon his experience with the beekeeping industry of Canada. This part is likely to be controversial, for Winston foresees the Africanized bee having "a devastating effect on our beekeeping systems". He points out that some 40 per cent of the 3 million honeybee colonies in the United States are moved each spring from the southern to the northern states, in accordance with the timing of different crops that need pollination or offer honey production, and that such large-scale bee movement would spread the Africanized bee beyond its natural range within the southern states. To reduce the impact of Africanized bees in the United States. $\mathrm{He}$ recommends prohibiting migratory beekeeping between areas with and without the Africanized bee. Also, given the difficulty of managing colonies of the feisty and swarm-prone Africanized bee, Winston recommends mandatory annual requeening of all beekeepers' colonies in Africanized zones, using certified queens of European descent. This would require shifting the production of queen bees from its current setting, in the southern states and California, to parts of the world without Africanized bees Europe, the northern United States, and islands such as Hawaii.

People working within some parts of the US beekeeping industry may be irritated by recommendations like these. Nevertheless, as a unified account of the biology and impact of the Africanized bee, the book must be reckoned with by anyone involved with the immigration of this insect into the United States.

Thomas D. Seeley is in the Section of Neurobiology and Behavior, Cornell University, Ithaca, New York 14853, USA. 